\title{
Between Historic Sites and New Tourist Destinations: The Development of the First Periphery in Medium-sized Andalusian Coastal Cities (1950-1980)
}

\author{
By Daniel Navas-Carrillo* \\ Carlos J. Rosa-Jimenez \\ M. Teresa Pérez-Cano
}

This study aims to analyze the urban growth experienced in the third quarter of the 20th century in medium-sized cities (1950-1980). These cities can be considered as relevant referents in their countries, although their population is lower than in regional centres (over 10,000 to 100,000 inhabitants). Furthermore, they have been recently recognized as an opportunity to promote more sustainable territorial strategies. Nevertheless, there are still gaps in many fields. The so-called first urban periphery was built in response to urging quantitative needs of the European existing housing. This was at the end of the mid-century wars, due to massive migration from the countryside to the cities in the whole continent. Sharing many of the morphological and pathological features with their equivalents, Spanish cities would have introduced certain peculiarities in their development because of the sociopolitical context marked by strong state control. This general framework of housing was completed with the implementation of some policies developed in the 1960s. Tourism was used as one of the growth engines of Spain's economy. Within this context, this research takes the Andalusian coast as a geographical framework and it intends to identify two different processes that have determined the urban development of these cities. On one hand, there are urban areas that have experienced a progressive demographic growth and have remained within the population range that defines a medium-sized city during this time. On the other hand, many towns have undergone an exponential evolution, moving from the features assimilated to rural settlements, to qualities of a medium-size city. In the final analysis, the purpose of this paper is to examine how historic sites have responded to this duality, as well as to determine if their protection has been decisive in the type of development that they have experienced.

Keywords: Medium-Size Cities, First Urban Periphery, Social Neighbourhoods, Tourism, Historic Site Protection.

\footnotetext{
* Pre-doctoral Researcher, Department of Urbanism, Higher Technical School of Architecture, University of Seville, Spain.

${ }^{\dagger} \mathrm{PhD}$ Lecturer, Department of Art \& Architecture, Higher Technical School of Architecture, University of Málaga, Spain.

* Senior Lecturer, Department of Urbanism, Higher Technical School of Architecture. University of Seville, Spain.
} 


\section{Introduction}

The Neighbourhoods of the First Periphery in Medium-sized Cities as a General Research Topic

The neighbourhoods of the so-called first periphery of European cities are the subject of this study. This work defines 'first periphery' as an urban expansion area built due to the "urgent residential needs that existed in Europe at the end of the mid-century wars in response to the transfer of rural-urban population"(Molina\& Rubio, 2010). They are also recognised as areas that have grown without an overall view, "urbanised territories where the concept of the city is absent" (Arteaga, 2009) following the precepts of the modern city of the Charter of Athens (1933). This urban manifesto - that emerges from the Fourth International Congress of Modern Architecture - applied for confronting social and political emergencies that classical planning had failed to resolve by decomposing the city into different functions. Thus, "the Fordist specialisation of space was given by correct, and thereby the city of residence" (Pie, 2009), and it defended a urban model based in the progressive expansion of cities.

In contrast to this view, the first reference in the defense of reusing the existing city can be located in Italy during the eighties. Secchi (1989), who was completely against the tide, postulated: "the city and the territory where we will live in the next few years are already built". This statement was faced with the logic of unlimited growth that had been inherited from the model of urban planning of the modern city. The development of the cities should not be focused on the uncontrolled growth, but should aim at improving the quality of life of its inhabitants, by means of recognising the heritage value of the existing city. In this sense, Secchi defended the history as a basis "to look for prints, signs and paths that would help to restore broken connections and find meanings to different urban fragments without denying the diversity " (García Vázquez, 2004).

If in the past two decades, the focus of the debate was on the recovery of historic centres, while the challenge of the $21^{\text {st }}$ century is located in the residential neighbourhoods although the importance of addressing their recovery lies in the demographic volume that represents the relationship with the rest of the city ${ }^{1}$. Furthermore, it should be understood as pieces that were built to provide a quick and low-cost answer to the population that was arriving from the countryside. However, the issue transcends the purely material fact by distinguishing "architectonic, urban and social problems" (García Vázquez, 2010). The high level of obsolescence - according to current comfort standards - has transformed these neighbourhoods into unattractive places for private investment, as a result of the articulation of contemporary urbanism solely in economic terms. This has triggered a process of social fracture, which in these areas has ended up concentrating the most depressed social classes.

\footnotetext{
${ }^{1}$ According to the Special Report about Census 2011, elaborated by the Observatory of Housing and Land (Ministerio de Fomento, 2014), in Spain around $40 \%$ of the homes were built between 1950 and 1980, tp house about $80 \%$ of the urban population.
} 
Figure 1. Sanlúcar de Barrameda: Public Neighbourhoods Built between 1950 and 1980

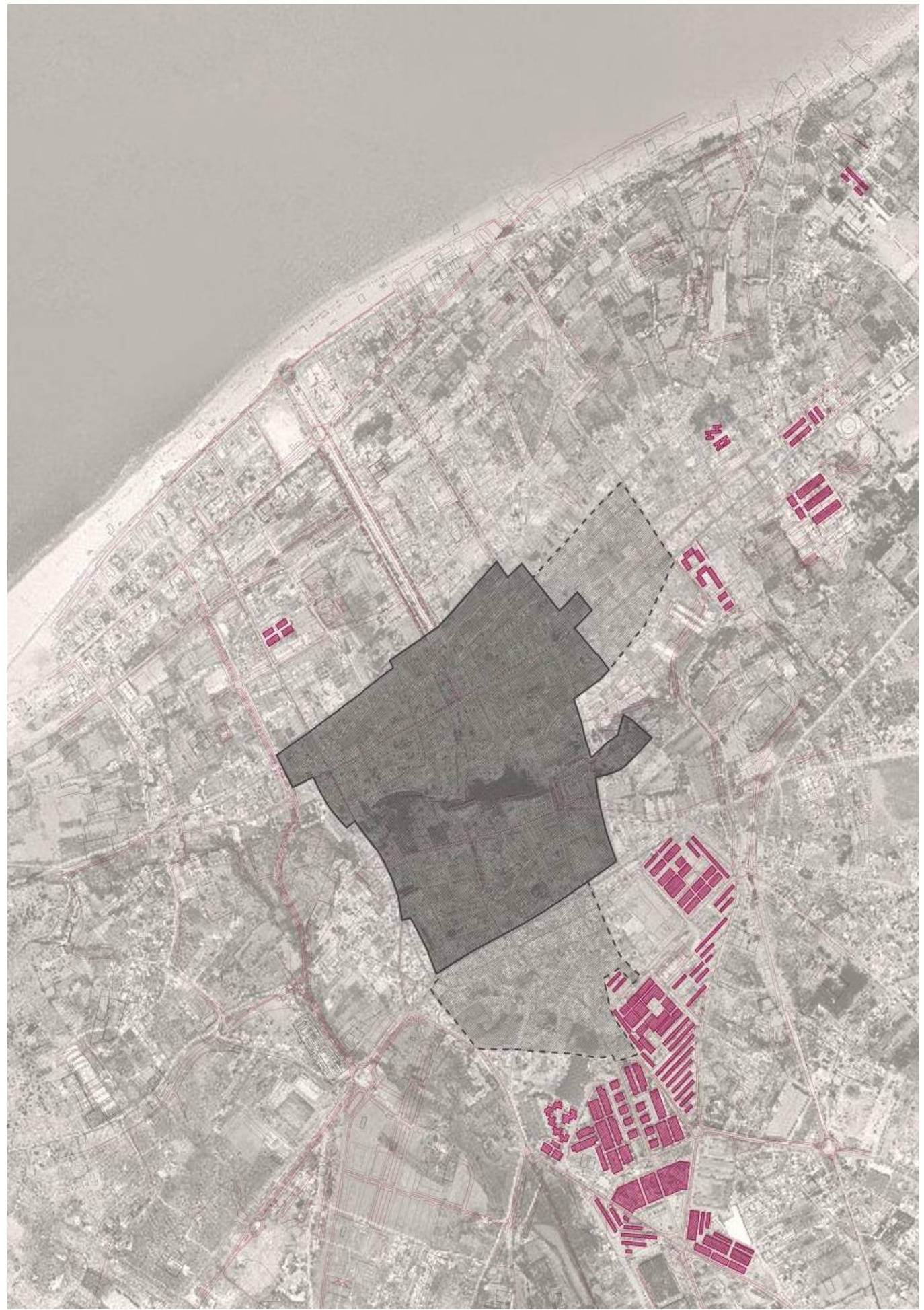

Source: Compiled by author from Digital Panchromatic Orthophoto of Andalusia (2016)

Paradoxically, they are pieces that remain in a strategic position between historic centres and new outskirts developments (see Figure 1). This outlines 
that areas of opportunity, in the evolution towards sustainable city models are based on the recovery of inherited housing, by completing and strengthening what already exists in response to the challenges of today's society.

Moreover, research has found a gap in the analysis of a range of municipalities. Although they have a lower number of promotions, their strategic position within the territorial structure of the region also stands as recipients of these migration processes. They are called medium-sized cities, which are monopolizing the role of management strategies and territorial development policies within the European Union ${ }^{2}$.

As will be discussed later, the definition of a medium-sized city should not be exclusively composed with demographic terms. It should be viewed, according to its strategic position, as a centre of first or second level within the functional organization of its region and far from the synergies of the main regional centres. Although incipiently and without important results, in the 1960s, many countries of the European Union focused part of their development legislation in boosting medium-sized cities. This was a measure to curb the processes of depopulation of rural areas that were causing severe overcrowding problems in larger cities.

The current interest differs clearly from the original one and is centered in sustainability criteria. The new perspective stands up for a polycentric territorial model, where each of these centres is "likely to generate growth and development in its immediate environment and balance the territory against monocentric metropolitan areas" (Casas et. al., 2003). In this regard, a special interest in the quality of life is rising recently. Intermediate cities lack many of the environmental problems of large cities. Also, their urban scale makes them more human and accessible cities. In addition to this, they lead to a more rational use of resources, ensuring the access to specialised goods and services under similar conditions to large urban areas (Méndez Gutiérrez et. al., 2008).

\section{Literature Review and Contextualization}

The Study of Neighbourhoods of Social Housing in the Second Half of the $20^{\text {th }}$ Century. Spanish Cases within the European Context

There are many authors who have dealt with this subject of study neighbourhoods, housing developments, grand ensembles, housing estate, Grofsiedlugen, etc. from various disciplines and approaches. There are frequent studies about the typological and morphological aspects but in most cases they are made from a local approximation.

In this regard, the work that has been done by DOCOMOMO, since its creation in 1988, has become the main international reference in

\footnotetext{
${ }^{2}$ According to the Statistics on Housing in the European Union, made on the occasion of the informal meeting of Ministers of Housing in September 2010 in Denmark, about $40 \%$ of the European population lives in municipalities with a population between 10,000 and 250,000, which it is already a first supporting reason to address this range of cities as an object of study.
} 
documentation of the architecture and urbanism of the Modern Movement. This nonprofit organization is primarily dedicated to the study and documentation of this architecture, in order to achieve its protection and conservation, as part of the culture of the $20^{\text {th }}$ century. It is responsible for an extensive literary production with international purposes, including monographies on social housing (Glendinning, 2008; Tostões \& Ferreira, 2016).

The cases analysed in these publications share many of the morphological and typological features with their European counterparts. However, housing policies developed in Spain after the Civil War - within a socio-political context marked by strong control of the Government - distinguish Spanish cities with certain peculiarities in their development. In those years, housing policies were connected to established economic guidelines. This allows recognising the three followings stages: Autarkic (1939-1955), Stabilisation (1956-1960) and Developmentalism (1961-1976). In each of these phases, different regulations about housing were approved, but the same objective was underlying in all of them: responding to the persistent problem of overcrowding in large and medium-sized cities.

Sambricio $(2003 ; 2008)$ is one of the main authors who have dealed with the study of social housing in Spain, providing a comprehensive approach with a global conception. At the same time, it is interesting to analyse the works of MonclúsFraga and Díez Medina(2015), due to the defense of the international character of these developments. This approach also includes the works that were carried out within the research group Social Housing, directed by Moya González, at the Polytechnic University of Madrid, many of which are compiled in the publication Social housing in Europe: Germany, France and Netherlands since 1945 (Moya González, 2008). This work intended to assess the level of adaptation of international solutions to the social, political and economic Spanish context. Their conclusions match with many of the contributions made at the International Congress German and Italian Models for Spain in postwar years, held in Pamplona in 2004 (Pozo Municio \& López Trueba, 2004).

From the Overcrowding Problems in Large Urban Agglomerations to the Repopulation of Rural Areas through "Colonisation Villages"

The large number of houses that were built in cities such as Madrid, Barcelona, Valencia and Seville, in response to the severe overcrowding of that time, justify that much of the studies conducted on social housing in this period are focused on the greater cities of Spain. The aforementioned authors, Sambricio(2004) and Moya González (1983), have studied the case of Madrid in numerous texts. Their publications systematically collected the characteristics of its urban growth in those years, which was the benchmark for the development of many cities in the rest of the country.

In other geographical contexts, we can point out studies by Gaja Díaz (1989) for the case of Valencia, Gutiérrez Mozoand Caro Gallego (2015) for 
Albacete or Bernal Santa Olalla (2009) in Burgos. In the case of the main regional centres of Andalusia,it should be highlighted the work of Reinoso Bellido(2005) on the construction of Málaga and the dissertation of Queiro Quijada (2016) about social neighbourhoods in Seville.

Similarly, as a result of the policies of transformation of the agricultural space for the settlement of self-sufficient rural peasantry, the called colonization towns would have arised, which intended to stop the strong migration processes from the countryside to the city. More than 300 settlements were built by the initiative of the National Institute of Colonization in 1939, under the Ministry of Agriculture, in order to justify the extensive research that the scientific community has made on all of them (Pérez Escolano, 2005; Calzada Pérez, 2006; Luque Ceballos \& Guerrero Quintero, 2008; Centenas Soler, 2010; Cabecera Soriano, 2014).

This approach to the object of study, envisions a range of cities that have not yet been studied. They do not have the same number of promotions that larger cities have, but their strategic position within the territorial structure of the region, also placed them as a centre of migration processes of that time.

\section{Medium-Sized Cities. A Problem of Definition}

One of the main conclusions, reached in the relevant state of the art on medium-sized cities, is on the discrepancies in their definition and are briefly recapitulated here.

The first discrepancies arise from the origins of the term. Some authors situate, as a background, the first notions about the concept of the development centre, at a regional level (pôle de croissance) used by Perroux (1955), in order to explain how economic growth occurs and the reasons why every growing process tends to be unbalanced. However, it is contrary to the central place theory of Christaller (1933), extended by Lösch (1940) in his book The Economics of Location, which is the first reference for other researchers. While Hirschman (1958) with his work The Strategy of Economic Development, combines both theories to give it a sufficient theoretical body to its use in spatial planning, emerging as one of the measures used in the decade the 60's for the promotion of the later called, intermediate cities.

The first who made use of the term 'intermediate city' was the French geographer Gault (1989) ${ }^{3}$. Followed by studies of the French Bouinot (1991) and Laborie (1993), as well as publications of the American researcher Plotnicov (1994). In Spain, the first who would have analyzed the role of medium-sized cities, in the territorial organization of the country, were Esteban Alonso and López López (1989). Years later, they were followed by the publication of Delgado Viñas (1995), Enguita Pueblaand Lopez (1995) and Vilagrasa Ibarz (1999).

All these works are mainly focused on finding a definition (Andrés López, 2008) and they constitute the prelude to the Urban Studies Week in

\footnotetext{
${ }^{3}$ The works of Silvia Blitzer (1988) on Small and Intermediate Centres in the Third World have been previously published.
} 
Intermediate Cities and World Urbanization, held in Lleida in 1998. The main conclusions and results were compiled in The medium or intermediate cities in a globalized world (Bellet Sanfeliu \& Beltrao Sposito, 1999), which is the main antecedent of the UNESCO report on intermediate cities in 1999 (Bellet Sanfeliu \& Llop Torné).

This report points out the main problems of defining the demographic issue. If at the European level, the average population of an intermediate city is between 20,000 and 500,000 inhabitants, Americans would consider populations between 200,000 and 500,000, reaching, in the case of Argentina, to expand the range between 50,000 and one million inhabitants. The discrepancies are obvious, if we consider that according to Plotnicov (1994) the size of these cities should not be measured in absolute terms, but in their expression-size range. With this, he refers to population ranges that characterize the territorial occupation of all cities and that will define - in demographic terms - what is meant by medium-sized cities in each territory.

This does not mean that the network of medium-sized cities can be identified in any context, such as occurs in Great Britain, Canada or Australia. Nor is there always a harmonious distribution among the various urban scales, such as it happens in the case of Mexico, where the major cities double in number to the intermediate ones, closer to the rural area. So we could wonder how can we recognise the role of medium-sized cities in their territory.

According to Bellet Sanfeliu and Llop Torné (1999), the concept of medium-sized city should go beyond the simple intermediate position between the upper end, large metropolitan areas, and the lower, rural areas. It requires contextualization by basing on the socioeconomic and cultural conditions of each territory and determining the role of each municipality, regardless of the number of people they have ${ }^{4}$.

These authors point out that the main characteristics that define them would be a servant centre of goods and services for the municipality and the nearest ones; as well as being the centre of social, economic and functional interaction ${ }^{5}$; while having a closer relationship with networks of local, regional, national or international infrastructure; or having regional administration services for other nearby municipalities.

This report has been a turning point in terms of the definition of the concept. So once it was overcome, other aspects seeking the development of these cities, from the economic and organizational question, were analyzed (Léo et. al., 2010), even from aspects of innovation (Méndez Gutiérrez, 2002; 2006; Pérez Prieto \& Marmolejo Duarte,2008) or related to the knowledge society(Méndez Gutiérrez \& Romeiro, 2008).

\footnotetext{
4 "The medium-sized cities articulate the territory and serve as referral centres for more or less immediate territory. And it is precisely that role and that relationship which centres have with their territory, helping to define more clearly the concept" (Bellet Sanfeliu \& Llop Torné, 1999).

5 They use the term "economic heart" taken from studies of Hardoy and Satterthwaite (1996) about territorial structures in the Third World.
} 
The Medium-sized Cities in the Andalusian Coast Corridor as an Object of Study

Andalusia is the southernmost region of Spain. It has more than 8 million inhabitants spread over a territory of $87.268 \mathrm{~km}^{2}$, which makes it the most populous region and the second largest in the country. Regarding its territorial structure, if there is a fundamental characteristic that defines Andalusia, it is the weight of the system of medium-sized cities in their functional organization. This fact is higher than in other Spanish or European regions (Sánchez Escolano, 2009) and it is essential for the current and future organization of the territory (Rodríguez Martínez \& Sánchez Escolano, 2010).

Figure 2. Andalusian System of Cities

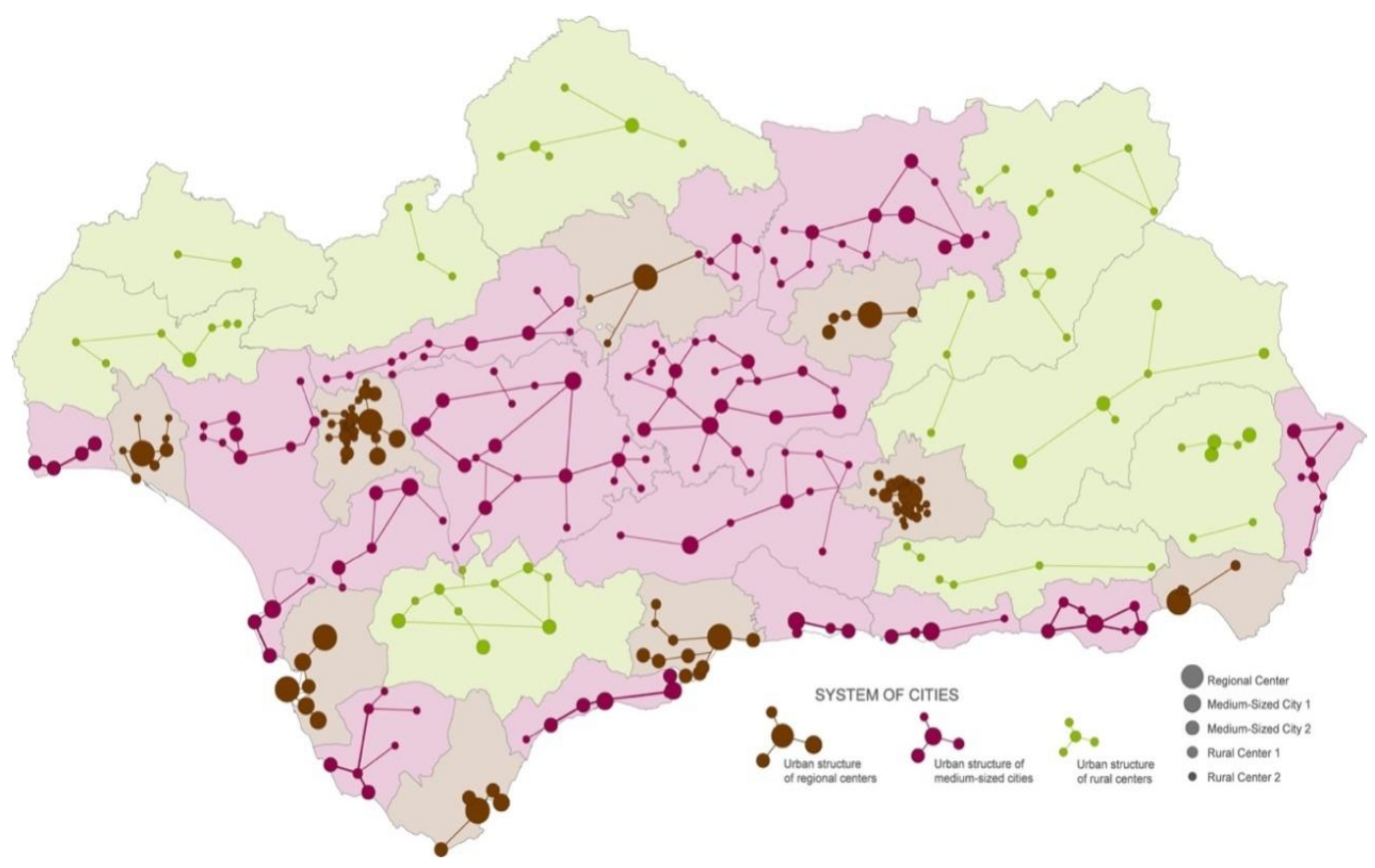

Source: Compiled by author from POTA (Junta de Andalucía, 2006)

This recognition underlies the drafting of the Territorial Plan for Andalusia in 2006 (here and after referred to as 'POTA'), which proposes a territorial hierarchical structure that is called System of Cities (See Figure 2), distinguishing three categories of cities: Regional Centres, Medium-Sized Cities and Rural Centres. The system of medium-sized cities identifies in turn two scales or internal levels, understanding that approximately $60 \%$ of the territory is under the influence of one of them. Approximately, $15 \%$ of the region inhabitants are living in a medium-sized city. But the plan goes further and argues that the dimensions and characteristics of medium-sized cities enable a compact urban model, in which growth can be controlled in order to limit excessive land consumption. 
According to this, they also guarantee the conservation of values and characteristics of these cities, while the aim is to increase the quality of life of its inhabitants completing the existing infrastructures and provisions to ensure the economic development of the region.

This territorial structure is heir to the regional division proposal (Junta de Andalucía, 1983) developed by the Regional Ministry of Territorial Policy. This proposal was finally not approved, but it would be published as a study entitled Andalusia, System of Cities (Junta de Andalucía, 1986) and slightly revised in the Basis for Territorial Planning of Andalusia, elaborated by the Regional Ministry of Public Works and Transport (Junta de Andalucía, 1990). In the same year, this Regional Ministry was in charge of organizing a conference on medium-sized cities in the city of Baena (Córdoba), that brought together leading researchers that had been working on the subject until that date.

Among them, Feria Toribio $(1984 ; 1993)$, should be mentioned due to the importance of his work in the drafting of these preliminary studies. He has developed extensive studies for the Andalusian territory based on the theory of central places, which was analyzed in his $\mathrm{PhD}$ dissertation (1984). Since then, he has developed many other reference works (e.g. Territorial systems of settlements in Andalusia: basic dimensions and territorial organization, 1993). Cano García $(1990 ; 1995)$ has also a prolific scientific production on the subject with publications such as Hierarchizing of Andalusian Urban Centres (1990) or Regions and articulation of the territory. Four Andalusian Examples (1995).

In these documents, a hierarchical system was already established, based on four levels: regional capital, sub regional centres, intermediate centres and basic centres. The latter two levels - between 100,000-20,000 and 20,000-5,000 inhabitants respectively - are a first approximation of the current system of medium-sized cities. While the current plan assumes the upper limit of 100,000 , the lower one is fixed to 10,000 . It still recognizes two types of medium-sized cities, but does not set an intermediate demographic threshold for tiring them.

According to the POTA, this classification has been made according to "demographic size, diversity and dynamics of its economic base and functional weight" without a clear definition of them throughout the whole document. It has been found that - excepting for certain exceptions- first-level cities have populations between 100,000 and 30,000, while second-level ones have smaller populations between 30,000 and 10,000 inhabitants. However, as it has been pointed out by authors like Cano García (2008), this distinction is more due to a central position within its territorial units that a matter of size or functional specialization, although both circumstances are coincident in most cases.

In this respect, it is worth mentioning the functional division set by the POTA. This recognizes two levels of functional specialization below the regional centres: the basic and specialised centres. Unlike what may be thought a priori, this classification does not correspond to the system of cities, but has to do with the fact that these municipalities assume complementary functions, 
facilities and equipment of supra-municipal nature as reference centres within their territorial units ${ }^{6}$.

Since the POTA became effective in 2006, a considerable number of researches have proliferated, constituting a theoretical reference to approach to medium-sized cities in Andalusia. Among other works, the following studies should be cited: Díaz Quidiello (2007), Rodríguez Martínez(2008), Caravaca Barroso; González Romero; Mendoza Bonetand Silva Pérez (2009), Sánchez Escolano (2009), Rodríguez Martíneza nd Sánchez Escolano (2010) ${ }^{7}$.

In the recent years, the publications derived from the thesis of Campos Sánchez (2012)- held in the Department of Urban and Regional Planning at the University of Granada-and the doctoral studies of Del Espino Hidalgo (2015) within the research group HUM 700, Heritage and Urban Territorial Development in Andalusia, based in the University of Seville- should be highlighted.

The cross-analysis of these works allows us to draw the conclusion that the definition of medium-sized cities that recognizes the POTA - from functional considerations and population range between 10,000 and 100,000 inhabitants has been accepted and verified in most of these researches, which have focused on their analysis from contemporaneity. This paper assumes the structure proposed by the plan and aims to provide a new perspective about it, introducing considerations related to the urban growth experienced by these cities between 1950 and 1980 .

\section{Methodology}

This paper aims to analyse the urban growth experienced in the third quarter of the 20th century by medium-sized cities of the Andalusian coast through the construction of social housing and the influence of two factors: urban growth synergies of new tourist settlements in contrast to the growth limitations established by the protection of historic sites as monuments.

As Terán Troyano (1996) argues, the adoption of the Land Law in 1956, radically changed the way of growth of the Spanish city based on social housing. Until that moment, there were small-scale promotions within historic sites, especially in medium-sized cities. But the appearance of the Partial Plan favored the construction of large urban areas, which have traditionally been known as neighbourhoods or housing estates. In the words of Ferrer i Aixalá (1998), these urban pieces should be understood as operations in which the phases of parcelling, urbanization and construction should be managed at the

\footnotetext{
${ }^{6}$ All first-level medium-sized cities are considered as specialised functional centres, while the second-order ones are both basic and functional specialised centres. Additional complexity factors must be added to this fact. For instance, there are also two levels for each of these types of functional centres, or some rural centres are also considered specialised centres.

${ }^{7}$ Some of them have also been referenced all nationwide. The importance of medium-sized cities in Andalusia, has placed the region researchers at the forefront of this matter.
} 
same time. They are characterised morphologically as minimum urban units with sufficient entity and clear urban limits (see Figure 3).

Figure 3. Neighboorhood of Carranque in Málaga (1967)

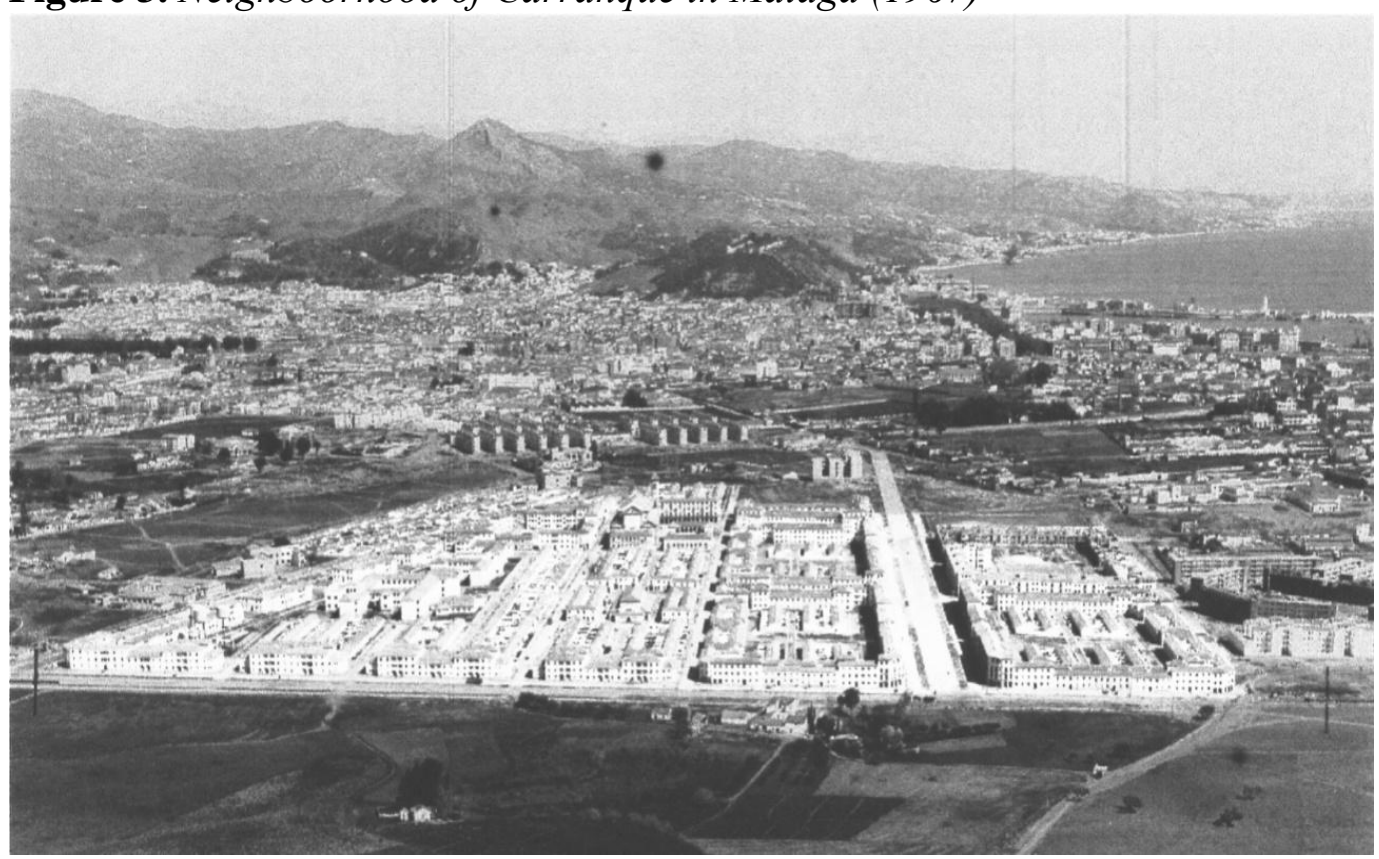

Source: Historical Archive of the province of Málaga

This study takes this definition to draw research boundaries. Firstly, those related to the scale of these embodiments. Although the Land Law favored operations of large areas, research, it has found that, on the type of cities, promotions of disparate dimensions were constructed ${ }^{8}$. This requires excluding from the residential study the groups with a small number of houses, which has been limited to 200 units. Secondly, the timeframe within which they were mostly made (1950 - 1980), focusing on plans since 1950, when the first draft of the Land Law was being written. Futhermore, according to Campos Sánchez and Abarca Álvarez (2013) the first urban expansion took place in Andalusian medium-sized cities during this period of time.

Firstly, it is necessary to start with an approach from the territorial structure proposed by the Plan, identifying the network of medium-sized Andalusian coastal cities. After that, the population growth experienced by these cities during the third quarter of the 20th century has been analysed, using the historical series of the Municipal Register developed by the Institute of Statistics and Cartography of Andalusia (IECA). In order to recognise the growing trends, these data have been also studied until nowadays.

\footnotetext{
${ }^{8}$ There are small realisations with a number less than 10 houses concentrated in a single block; as well as others with more than a thousand homes, on plots of 10 hectares, allowing the diversity of buildings and typologies. This heterogeneity requires limiting the scale of the sets to study in relation to the objectives.
} 
The third aspect analysed was the number of public housing (either on the initiative of the administration or by private developers), built in this time frame. It is based on the housing plans discussed above and compared to the total number of constructed buildings. This information was obtained from the existing database at the Institute of Statistics and Cartography of Andalusia and the Central Archive of the Ministry of Public Works.

This general framework must be completed with the study of some policies developed in the '60s that were aimed at promoting international tourism as one of the growth pillars of the Spanish economy growth. This governmental objective coincided with the Stabilisation Plan of 1959, which established an economic model that encouraged inflows of foreign capital and international multinationals by searching support abroad for its economic policy. The so-called Law of Centres and Zones of National Tourist Interest (Law 197/1963), aimed to connect the economic and tourism foresights with regional planning. As it is indicated by Galiana Martín and Barrado Timón (2006), an ambitious model that reached a remarkable technical development, but that failed from a global perspective of littoral territorial planning, was attempted ${ }^{9}$. In spite of this lack of success, most of the National Tourism Centres have had a meaningful influence on their coastal regions and specific tourism development models as in the case of the Andalusian Coast. This paper attempts to show that these centres have also influenced on the growth and development of nearby medium-sized cities.

Finally, we have identified which of the founding cores of these cities have been declared as monuments, according to the different laws ${ }^{10}$ (national firstly, regional lately) that have been declared in Spain from 1933 to our days. Additionally, it has been also identified which of the cities declared part of the heritage cities networks under the POTA, understanding the territorial nature of the research. It seeks to identify if possible influences in controlling the growth of cities could be extended to other cities in the network, that had not been protected yet.

\footnotetext{
${ }^{9}$ The law was reduced to a simple figure designed to protect and promote urban tourist settlements, regulating the characteristics and conditions that the promotions must meet to apply for grants and benefits. In this sense, the Tourist Centre became a product of great interest to private investors due to the economic and legal advantages that the legislation granted the promoters. Consequently, these new tourist destinations were planned based on private interests, being that Public Administration depended on these promoters for the country's development (Sánchez Fuentes \&Gallardo Ramirez, 2015).

${ }^{10}$ Many Spanish historic sites were declared based on the law of defence, conservation and enlarging of the National Historic-Artistic Heritage (Law 13th May 1933). Currently, the law of Spanish Historical Heritage (Law 16/1985) is the rule in force for the entire national territory. These objectives were adapted to the Andalusian characteristics by the law of Andalusian Historical Heritage (Law 1/1991), which has been recently revised (Law 14/2007).
} 


\section{Results}

The Approach from the Territorial Structure proposed by the Plan

Within the set of medium-sized cities two situations should be recognized. The domain of the coast has a territorial structure that differs greatly from the interior model. Some of the reasons are the geographical position on the coast, the experienced strong economic and demographic development or the particular dynamics of urban growth, which tend to occupy the entire coastline, absorbing historic sites. Litoralis presented as an area of opportunity for the goals of this research.

\section{Figure 4. Medium-sized Cities System in Andalusian Littoral}

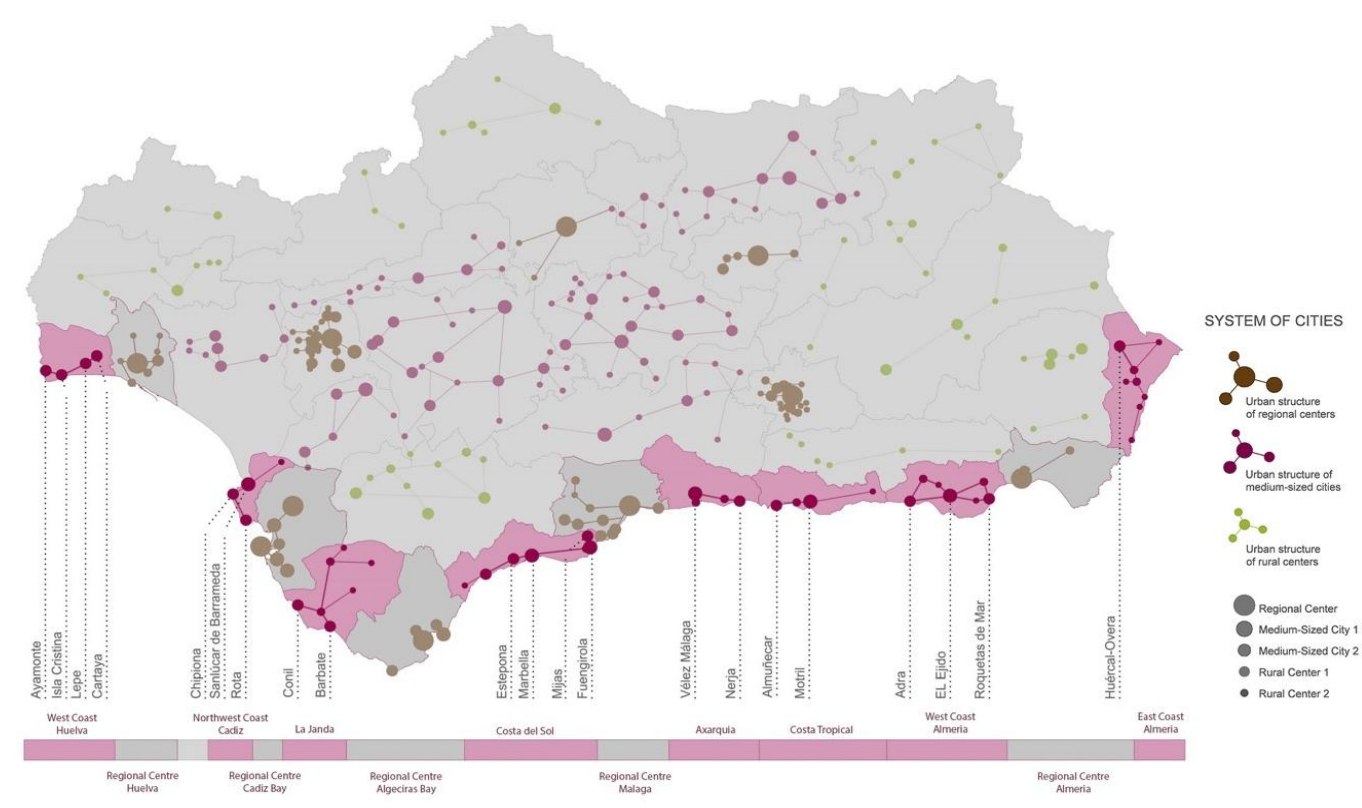

Source: Compiled by author from POTA (2006)

Within the territorial domain ${ }^{11}$ of the coast (see Figure 4), the plan recognises eight territorial units ${ }^{12}$ that link seven medium-sized cities of level 1 (Sanlúcar de Barrameda, Marbella, Fuengirola, Mijas, Velez-Málaga, Motril and El Ejido) and fourteen of level 2 (Ayamonte, Isla Cristina, Lepe, Cartaya, Chipiona, Rota, Conil, Barbate, Estepona, Nerja, Almuñécar, Adra, Roquetas de Mar and Huércal-Overa).

\footnotetext{
${ }^{11}$ Territorial domains are the basic components of the territorial structure design allowing strategic lines of action. Depending on their particular characteristics, four territorial domains have been established: Sierra Morena-Los Pedroches; Guadalquivir Valley; Mountains and Valleys Béticos; and Litoral.

${ }^{12}$ The general domains are subdivided into territorial units, characterized as "areas defined by their physical and functional homogeneity and to present common problems and opportunities in matters relating to economics, land use and management of resources" (POTA, 2006). This division comes to coincide with the System of Cities, having identified its main characteristics and defined strategies for functional organisation.
} 
In these units, two general growth trends have been identified. They are mainly based on economic and productive factors. On one hand, the Costa del Sol and the West of Almería emerge as strongly anthropised units, with a population of over 200,000 inhabitants. They have a mono-functional model (tourism and agricultural greenhouses, respectively). Furthermore, the territories of the West Coast of Huelva, Doñana ${ }^{13}$, La Janda, La Axarquía, the Costa Tropical and the East of Almeria are territorial units with an inferior level of occupation. Their functional model links up the previous two economic pillars - tourism and agriculture - with other specific development factors of urban, industrial and commercial economies.

\section{The Demographic Evolution of Medium Size Cities of the Andalusian Coast}

According to the demographic evolution (see Table 1) experienced in medium size cities of the Andalusian coast, they have been classified into the following types.

- Type E1. Cities that have maintained the category of medium sized (level 1 or 2) during this period of time. As for medium-sized cities of Level 1, Sanlúcar de Barrameda and Velez-Málaga, experience a growth of around 130\% in this temporal framework, based on a population that already in 1950 exceeded 30,000. Others like Motril, from a population of 20,000 inhabitants, experienced a slightly higher growth, $165 \%$, reaching 40,000 in the early eighties.

- In the case of level 2 medium-sized cities, the towns of Ayamonte, Isla Cristina, Rota (see Figures 5), Barbate and Huércal-Overa maintained a population between 10,000 and 30,000 inhabitants. Their growth ranges from $131 \%$-for the case of Ayamonte- and $200 \%$ in Rota, excepting for Huércal-Overa, reducing its population reduced by $18 \%$.

- Type E2. Cities that experienced a population growth in the 40 s \& 50s can be considered medium-sized cities (level 1 or 2 ) since the beginning of this period. For example, Cartaya, Lepe, Conil and Nerja, based on a population of less than 10,000 inhabitants in 1950, experiencing a controlled growth (between 120\% and 165\%), not in any case exceed the 30,000 inhabitants at the end of the period.

- Type E3. There is one last group of municipalities that experienced a much more significant population increase based on similar population data and even less than 10,000. These coincide with the average cities located in the Costa del Sol and Western Almería. In both units, growth between 200 and 400\% (Marbella-600\%, Mijas - 210\%, Fuengirola 430\%, Adra-496\%, El Ejido - 287\% and Roquetas - 200\%) percentages skyrocket, if is taken into account the population increase until today.

\footnotetext{
13 Doñana is a National Park which was declared as a nature reserve in 1969. Consequently, building construction is limited.
} 
Figure 5. Urban Evolution of Rota

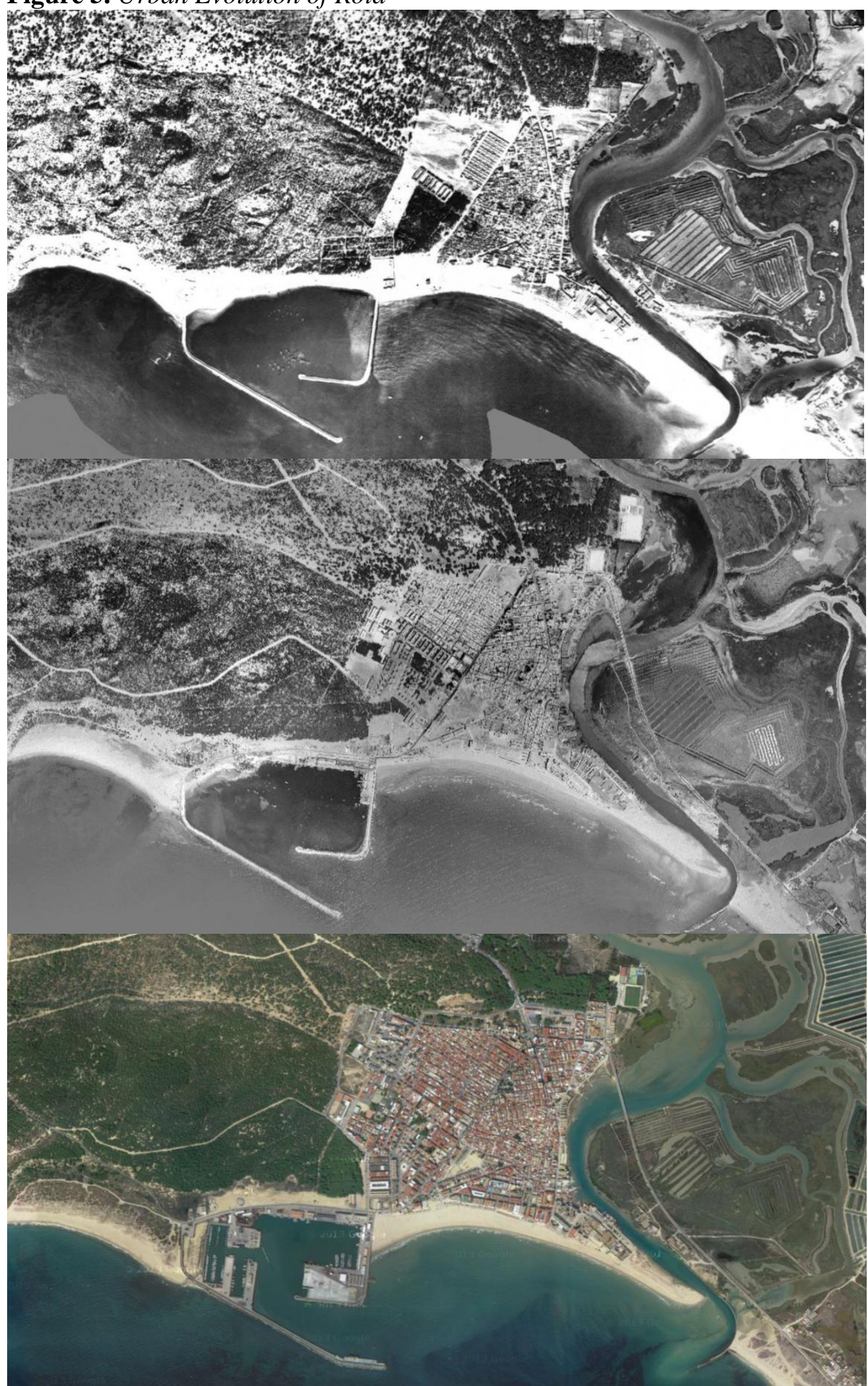

Source: Digital Panchromatic Orthophotos of Andalusia: 1956, 1976 and 2016 
Table 1. Demographic Evolution of Medium-sized Cities on the Andalusian Coast (1950-1980)

\begin{tabular}{|c|c|c|c|c|c|c|c|}
\hline \multirow{3}{*}{$\begin{array}{l}\text { Medium-Sized } \\
\text { Cities }\end{array}$} & \multirow{3}{*}{$\begin{array}{c}\text { Coastal Territorial } \\
\text { Units }\end{array}$} & \multicolumn{6}{|c|}{ Demographic Evolution } \\
\hline & & \multicolumn{4}{|c|}{ Number of Inhabitants } & \multicolumn{2}{|c|}{$\begin{array}{c}\text { Increasement } \\
(\%)\end{array}$} \\
\hline & & 1950 & 1980 & 2006 & 2016 & $\begin{array}{c}1950- \\
1980\end{array}$ & $\begin{array}{l}1950- \\
2016\end{array}$ \\
\hline Huércal-Overa & East Coast of Almeria & 14.020 & 12.289 & 16.170 & 18.374 & $88 \%$ & $131 \%$ \\
\hline Roquetas de Mar & West Coast of Almeria & 2.239 & 4.440 & 71.740 & 90.623 & $198 \%$ & $4047 \%$ \\
\hline El Ejido & West Coast of Almeria & 11.484 & 32.999 & 79.776 & 88.123 & $287 \%$ & $767 \%$ \\
\hline Adra & West Coast of Almeria & 3.811 & 18.891 & 23.545 & 24.782 & $496 \%$ & $650 \%$ \\
\hline Motril & Costa Tropical & 24.592 & 40.506 & 57.895 & 60.870 & $165 \%$ & $248 \%$ \\
\hline Almuñécar & Costa Tropical & 12.524 & 16.390 & 26.264 & 27.195 & $131 \%$ & $217 \%$ \\
\hline Nerja & La Axarquía & 7.123 & 11.589 & 20.361 & 20.649 & $163 \%$ & $290 \%$ \\
\hline Vélez-Málaga & La Axarquía & 31.948 & 41.937 & 67.697 & 77.808 & $131 \%$ & $244 \%$ \\
\hline Mijas & Costa del Sol & 7.175 & 14.777 & 61.147 & 77.521 & $206 \%$ & $1080 \%$ \\
\hline Fuengirola & Costa del Sol & 6.774 & 29.160 & 63.899 & 75.856 & $430 \%$ & $1120 \%$ \\
\hline Marbella & Costa del Sol & 10.027 & 60.172 & 125.519 & 138.679 & $600 \%$ & $1383 \%$ \\
\hline Estepona & Costa del Sol & 13.138 & 23.542 & 58.603 & 66.566 & $179 \%$ & $507 \%$ \\
\hline Barbate & La Janda & 12.086 & 20.806 & 22.602 & 22.861 & $172 \%$ & $189 \%$ \\
\hline Conil Fr. & La Janda & 9.245 & 13.406 & 19.890 & 22.063 & $145 \%$ & $239 \%$ \\
\hline Rota & Northeast Coast of Cadiz & 10.353 & 20.559 & 27.260 & 29.179 & $199 \%$ & $282 \%$ \\
\hline Chipiona & Northeast Coast of Cadiz & 6.607 & 12.484 & 17.952 & 19.004 & $189 \%$ & $288 \%$ \\
\hline Sanlúcar Bda. & Northeast Coast of Cadiz & 35.517 & 48.390 & 63.509 & 67.385 & $136 \%$ & $190 \%$ \\
\hline Cartaya & West Coast of Huelva & 7.007 & 9.098 & 16.042 & 19.168 & $130 \%$ & $274 \%$ \\
\hline Lepe & West Coast of Huelva & 9.285 & 14.053 & 23.781 & 27.054 & $151 \%$ & $291 \%$ \\
\hline Isla Cristina & West Coast of Huelva & 11.135 & 16.347 & 20.323 & 21.346 & $147 \%$ & $192 \%$ \\
\hline Ayamonte & West Coast of Huelva & 12.277 & 16.098 & 18.636 & 19.690 & $131 \%$ & $160 \%$ \\
\hline Average & Coastal Corridor & 12.303 & 22.759 & 42.981 & 48.324 & $213 \%$ & $393 \%$ \\
\hline
\end{tabular}

Source: Historical Series of the Municipal Register. IECA 
Table 2. Housing Construction in Andalusian Coastal Medium-sized Cities (1950-1980)

\begin{tabular}{|c|c|c|c|c|c|c|c|c|}
\hline \multirow{4}{*}{ Medium-Sized Cities } & \multicolumn{8}{|c|}{ Housing construction (1950-1980) } \\
\hline & \multirow{2}{*}{\multicolumn{2}{|c|}{$\begin{array}{c}\text { Total housing } \\
\text { Increase }\end{array}$}} & \multicolumn{6}{|c|}{ Public housing } \\
\hline & & & \multicolumn{4}{|c|}{ Total number of public housing groups } & \multicolumn{2}{|c|}{$\begin{array}{c}\text { Groups with more than } 100 \\
\text { homes }\end{array}$} \\
\hline & $\begin{array}{c}\text { Num. } \\
\text { of } \\
\text { houses }\end{array}$ & $\%$ & $\begin{array}{l}\text { Num. of } \\
\text { houses }\end{array}$ & $\begin{array}{l}\text { Public /total } \\
\quad(\%)\end{array}$ & $\begin{array}{l}\text { Num. of } \\
\text { groups }\end{array}$ & $\begin{array}{l}\text { Average houses } \\
\text { per group }\end{array}$ & $\begin{array}{l}\text { Num. of } \\
\text { groups }\end{array}$ & $\begin{array}{l}\text { Average houses } \\
\text { per group }\end{array}$ \\
\hline Huércal-Overa & 4338 & $36,22 \%$ & 186 & $4,29 \%$ & 7 & 27 & - & - \\
\hline Roquetas de Mar & 2223 & $26,60 \%$ & 206 & $9,27 \%$ & 5 & 41 & 1 & 200 \\
\hline El Ejido & 6573 & $35,28 \%$ & 105 & $1,60 \%$ & 2 & 53 & - & - \\
\hline Adra & 4039 & $24,77 \%$ & 450 & $11,14 \%$ & 9 & 50 & 1 & 100 \\
\hline Motril & 6020 & $49,01 \%$ & 727 & $12,08 \%$ & 9 & 81 & 4 & 136 \\
\hline Almuñécar & 2552 & $45,85 \%$ & 277 & $10,85 \%$ & 5 & 55 & 1 & 102 \\
\hline Nerja & 2484 & $36,50 \%$ & 93 & $3,74 \%$ & 3 & 31 & - & - \\
\hline Vélez-Málaga & 5745 & $36,13 \%$ & 169 & $2,94 \%$ & 3 & 56 & - & - \\
\hline Mijas & 5126 & $29,82 \%$ & 0 & $0,00 \%$ & 0 & - & - & - \\
\hline Fuengirola & 3504 & $49,22 \%$ & 222 & $6,34 \%$ & 3 & 74 & 1 & 122 \\
\hline Marbella & 6829 & $32,42 \%$ & 606 & $8,87 \%$ & 8 & 76 & 2 & 154 \\
\hline Estepona & 7469 & $46,91 \%$ & 477 & $6,39 \%$ & 4 & 119 & 2 & 362 \\
\hline Barbate & 2373 & $46,58 \%$ & 1395 & $58,79 \%$ & 13 & 107 & 4 & 930 \\
\hline
\end{tabular}




\begin{tabular}{|c|c|c|c|c|c|c|c|c|}
\hline Conil Fr. & 2117 & $25,88 \%$ & 152 & $7,18 \%$ & 3 & 51 & 1 & 120 \\
\hline Rota & 2644 & $36,09 \%$ & 1258 & $47,58 \%$ & 10 & 126 & 4 & 265 \\
\hline Chipiona & 3829 & $45,03 \%$ & 99 & $2,59 \%$ & 3 & 33 & - & - \\
\hline Sanlúcar Bda. & 4126 & $29,53 \%$ & 2300 & $55,74 \%$ & 14 & 164 & 5 & 386 \\
\hline Cartaya & 2037 & $42,11 \%$ & 227 & $11,14 \%$ & 7 & 32 & - & - \\
\hline Lepe & 2190 & $32,14 \%$ & 111 & $5,07 \%$ & 3 & 37 & - & - \\
\hline Isla Cristina & 1728 & $41,18 \%$ & 691 & $39,99 \%$ & 9 & 77 & 2 & 123 \\
\hline Ayamonte & 1378 & $31,06 \%$ & 516 & $37,45 \%$ & 12 & 43 & - & - \\
\hline Average & 3.777 & $37,62 \%$ & 489 & $12,94 \%$ & 6 & 67 & 2 & 250 \\
\hline
\end{tabular}

Sources: Evolutionary Series Homebuilding (IECA), Registry of public housing (including private initiatives) of the Central Archive of the Ministry of Public Works. 
The Construction of Social Housing (1950-1980)

The following table summarizes (Table 2) the relationship between the number of public housing and the total number of homes built in the temporal framework of the investigation. The research is based on the information obtained from the existing database in the Statistical Institute and Cartography of Andalusia and the Central Archive of the Ministry of Public Works.

According to these data, the cities under analysis can also be classified in these other five types:

- Type H1. Sanlúcar de Barrameda stands out as the municipality in which a larger number of public housing are built, 2,300 units spread over 14 promotions, representing more than $55 \%$ of homes built in those years.

- Type H2. Rota and Barbate have more than 1,000 public homes, representing respectively 48 and $58 \%$ of the total number of homes built in those years.

- Type H3. It has been identified a third group of cities whose public housing production was between 500 and 1,000 homes. These are - in an increasing order - Motril, Marbella, Isla Cristina and Ayamonte. In the first two cases public housing is not significant with respect to the total, while in the other two cases it is close to $40 \%$.

- Type H4. In other cities - except for Mijas- the number of public housing is between 500 and 100 houses, representing a percentage less than $10 \%$ of all homes built.

- Type H5. Mijas, is the only case that does not have any record in the database consulted.

Concerning the scale of these promotions, there have been identified for the whole sample only 28 groups with more than 100 homes, with an average of 250 houses per promotion, recognizing the following circumstances:

- Sanlúcar de Barrameda is the municipality where the larger scale neighborhood is located: Housing State El Palomar with 900 homes. They also highlight the following groups (see Figure 6): Jesús Nazareno (450 houses), El Carmen (264 houses), $\mathrm{N}^{\mathrm{a}} \mathrm{S}^{\mathrm{ra}}$ de los Angeles (200 houses) and San Lucas (200 houses). 
Figure 6. Largest Social Neighbourhoods in Sanlúcar de Barrameda

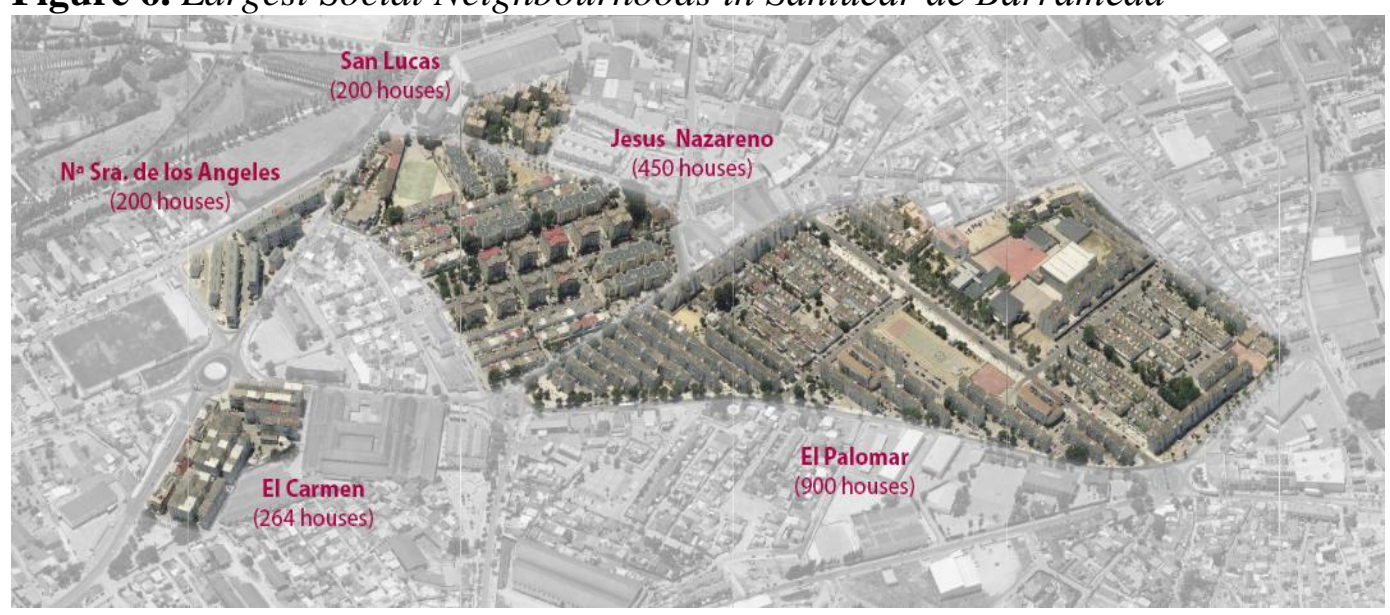

Source: Compiled by author

- In parallel with the data of all public housing, Rota and Barbate are located in a second scale. Both cities have a group of 500 houses, with two or three other cases of between 150 and 200 houses.

- From the rest of the medium-sized cities on the Andalusian coast, there have been identified neighbourhoods with a number of homes ranging from 100 to 200, in the municipalities of Isla Cristina (2 promotions), Conil de la Frontera (1 promotion), Estepona (2 promotions), Marbella ( 2 promotions), Fuengirola (1 promotion), Almuñécar (1 promotion), Motril (4 promotions), Adra (1 promotion) and Roquetas de Mar (1 promotion).

\section{Centres of National Tourist Interest}

According to the dossiers preserved in the Andalusian Central Archive, 27 Centres of National Tourist Interest were approved in Andalusia between 1964 and 1975: 5 centres in Málaga, 9 centres in Cádiz, 4 centres in Huelva, 4 centres in Almeria, 4 centres in Granada and 1 centre in Sevilla. Most of them (20) were placed in coastal areas, looking for "the valorisation of the land adjacent to hundreds of kilometers of beaches" (García Sánchez, 2012). Only 8 of these 20 centres were located in any of the medium-sized cities that have been analysed in this paper (see Table 3). 
Table 3. Andalusian Centres of National Tourist Interest
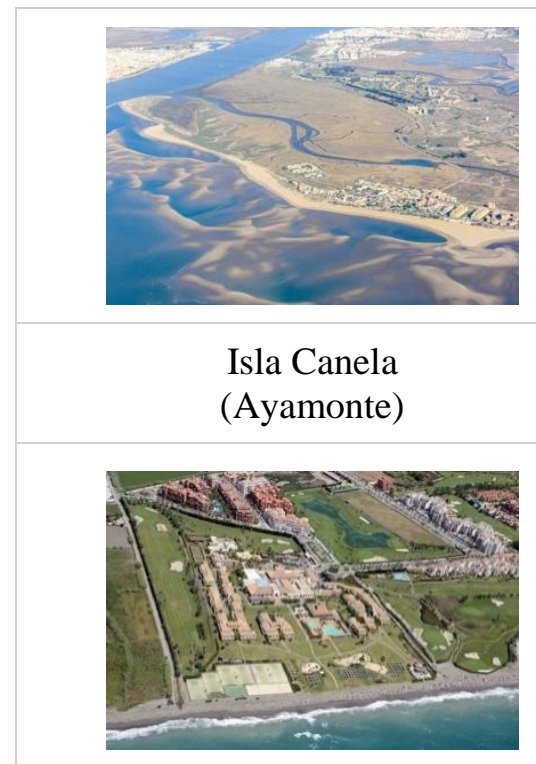

Playa de Granada (Motril)

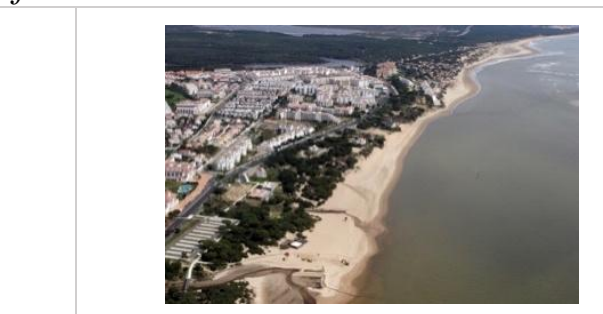

Nuevo Portil (Cartaya)

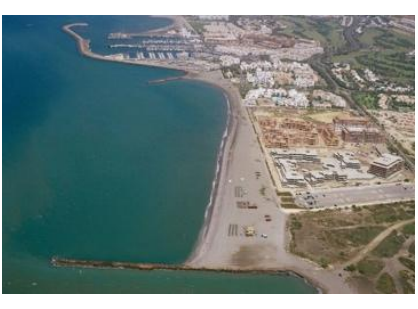

Almerimar

(El Ejido)

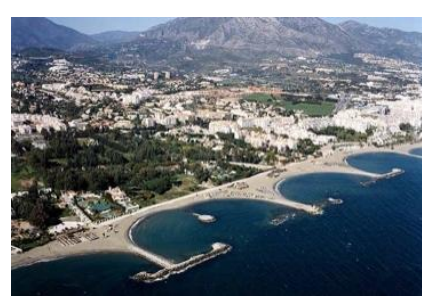

Nueva Andalucía (Marbella)

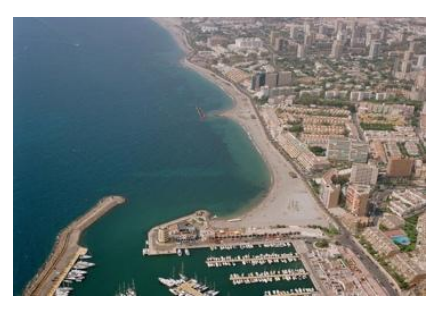

Aguadulce (Roquetas de Mar)

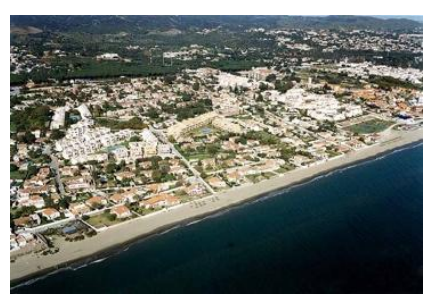

Pinomar (Marbella)

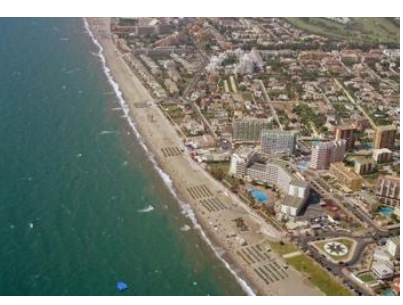

Housing Estate Roquetas de Mar

Source: 27 Centres of National Tourist Interest (García Sánchez, 2012).Source of Images: Guide to beaches. Ministry of Agriculture, Food and Environment 
Table 4. Historic Sites declared as Monument in Medium-sized Cites of Andalusian Coast

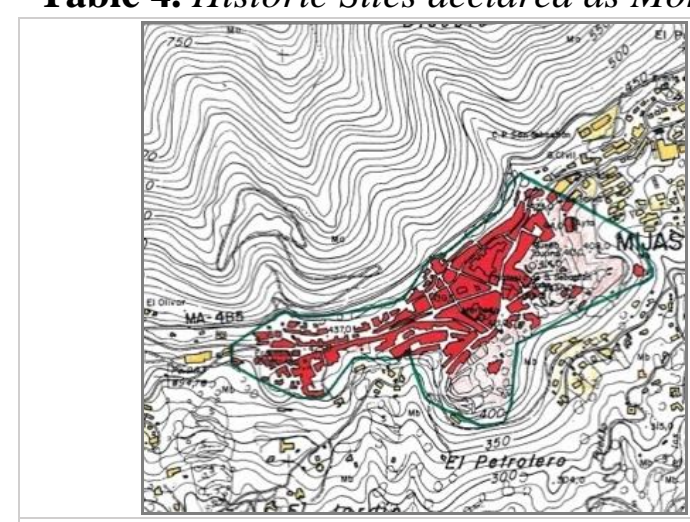

Mijas, 1969

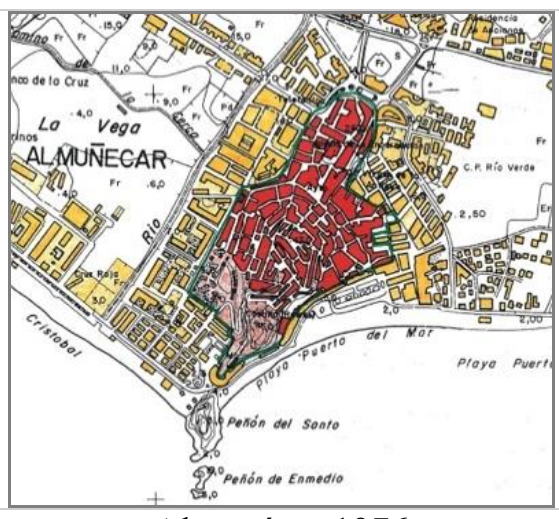

Almuñécar 1976

Reviewed in 2014, (Law14/2007)

.
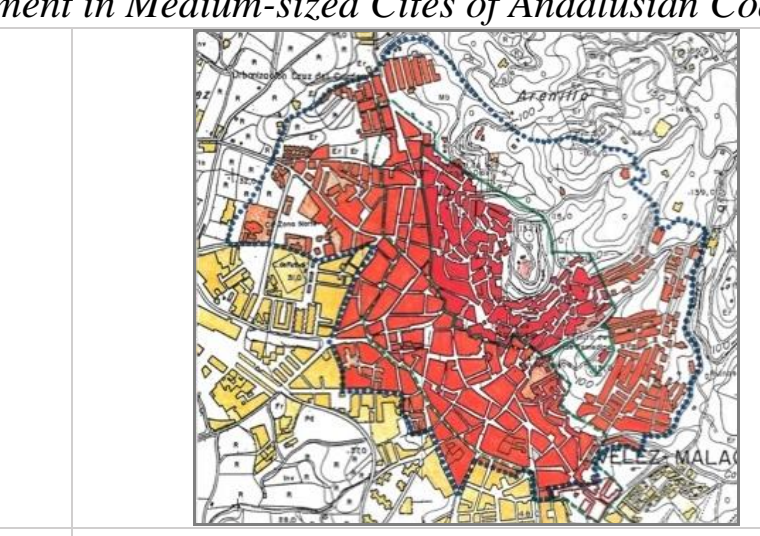

Vélez-Málaga, 1970, Reviewed in 2007

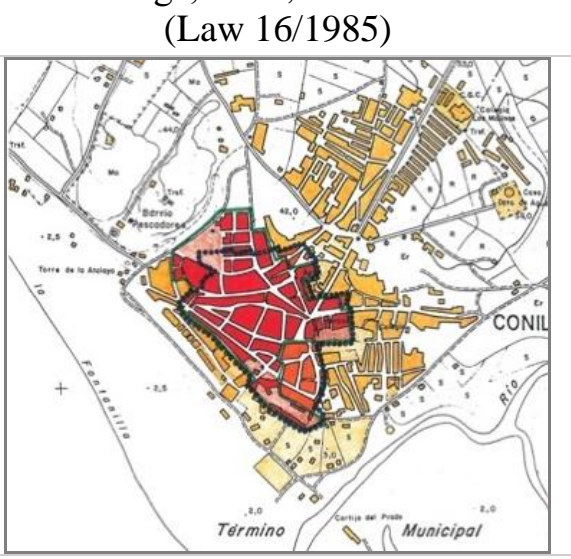

Conil de la Frontera, 1983

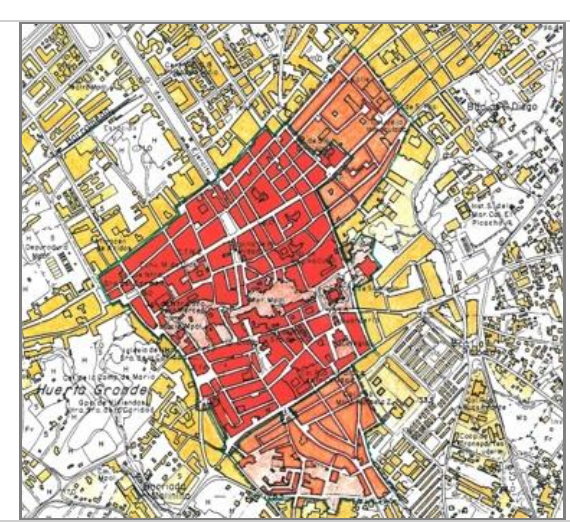

Sanlúcar de Barrameda, 1973

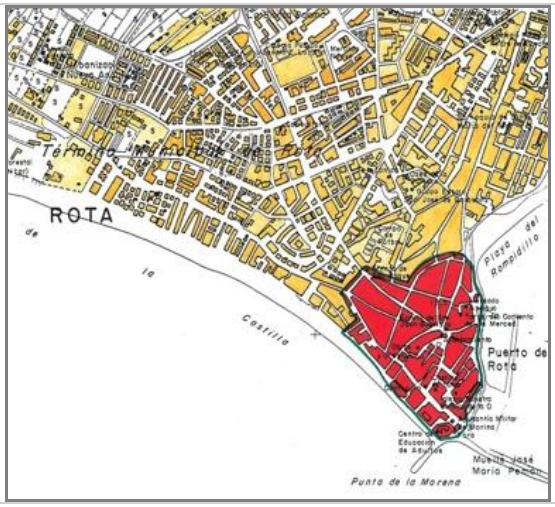

Rota ,1985

Reviewed in 2003, (Law 16/1985)

Source: General Catalogue of the Andalusian Historical Heritage (consulted on May 2016). Source of Images: Urban analysis of historical centres in Andalusia: medium and small cities (Junta de Andalucía, 2001). 
Marbella was the city where the largest number of accommodations were projected with about 76,000 units. These were divided into two areas: Nueva Andalusia (1964) - the largest centre of tourist interest of Spain - with 75,000 units and Pinomar (1965) with 936 units. These groups are followed by Isla Canela (1964) in Ayamonte and Nuevo Portil (1964) in Cartaya, with 46,500 and 40,000 units respectively. Almería was another province that projected new tourist destinations. In El Ejido (1967) Almerimarwas planned, with 16,190, while in Roquetas de Mar two groups were designed: Aguadulce (1968) with 6,932 units and the housing estate Roquetas de Mar (1968) with 9,000 units. Finally, the smallest centre, with 4,400 units, was placed in Motril and was called Playa de Granada (1968). The total number of accommodation units approved in these centres was around 2 hundred thousand units.

\section{Historic Sites Protection as Monument}

All historic sites that have been identified in the selection of the cities analysed, were declared based on the legislation of 1933, although three of them have been subsequently revised, as specified in table 4 .

As mentioned before, the municipalities which are part of the heritage cities networks under the POTA, have been identified. While all of them are integrated into a network of heritage cities, there are only two cases in which the network is consistent with the structure of the system of cities. These cases are the territorial units of the Northeast Coast of Cádiz (Sanlúcar, Chipiona and Rota) and Costa Tropical (Almuñecar and Motril), as illustrated in the figure below (Figure 7).

Figure 7. Networks of Heritage Cities and Historic Sites located in Mediumsized Cities of the Coast of Andalusia

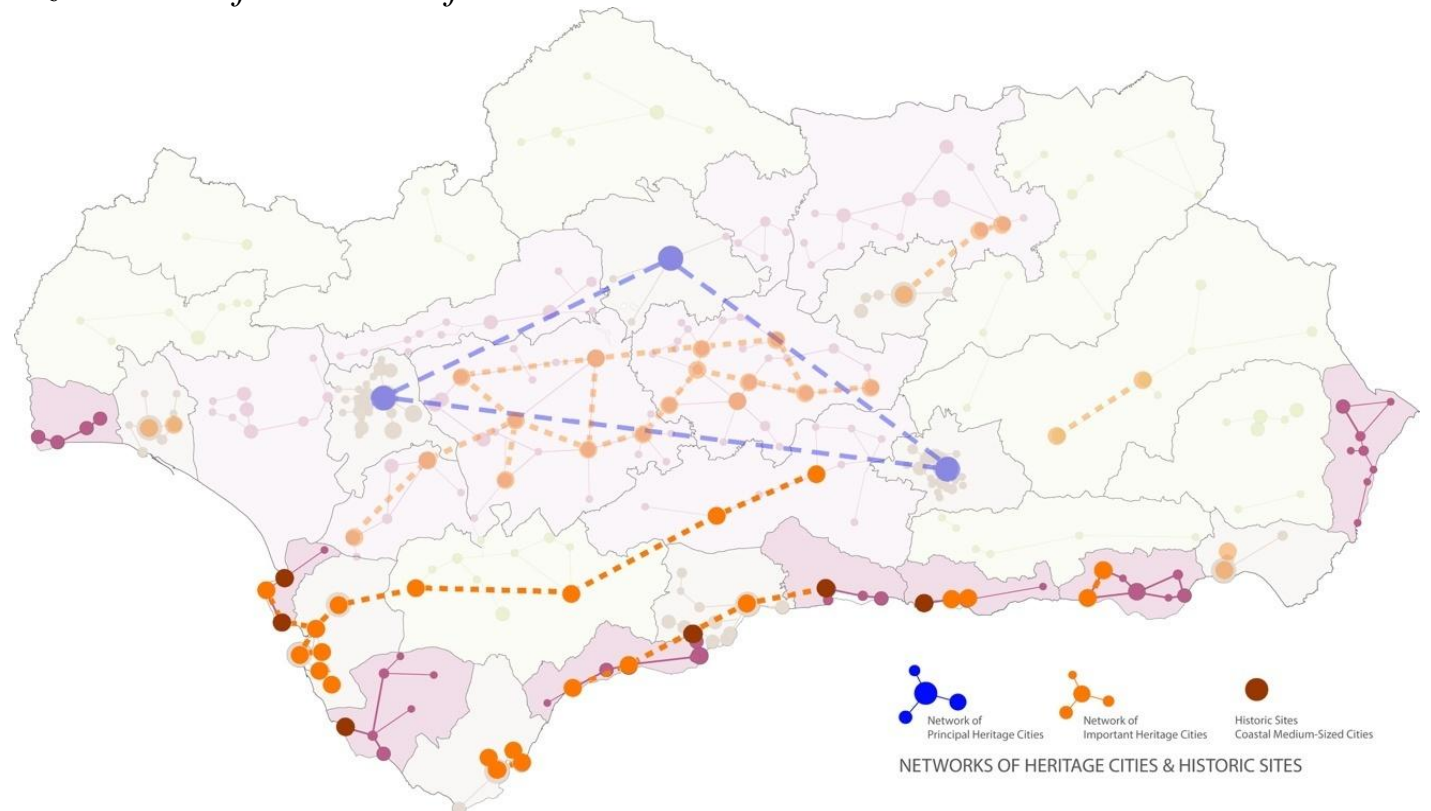

Source: Compiled by author from POTA 


\section{Discussion}

The cross-analysis of this information allows us to confirm the expected results. We have found a direct relation between the cities that have had a progressive demographic growth as a medium sized city and those whose historic sites have been declared as monuments. Moreover, in some cases, as in Sanlúcar de Barrameda or Barbate, there are also cities with a high number of public housing, in quantity but also in relation to the total number of residential buildings that were built in those years. They are also the cities with larger promotions unitarily built.

On the other hand, cities that had a tourism development at this time have retained this activity as its main economic engine. These are the cities that have presented the greatest population growth (1950-2016) exceeding, for example, $1000 \%$ for cases of Marbella and Roquet as. Consequently, interest in investment, which was caused in these cities in the private sector, has been accompanied by a greater number of private development homes against public investment. This is a result of the much lower percentage of public housing, comparing to the previous cases.

In addition, none of the Centres of National Tourist Interest were located in cities whose historic centres have been declared as monuments. Note that these declarations were after the construction of the majority of those touristic areas. This leads us to believe that the absence of these resorts in these cities has allowed conserving their historic centres, recognizing its heritage values a posteriori. At the same time, their protection has permitted to stop the latest tourist pressure. There is a unique exception: the case of Mijas ${ }^{14}$.

On the other hand, research has found that the existing information on the promotions of social housing built under the supervision of the National Housing Institute is in some cases incomplete and therefore needs to be checked and revised by in situ. On the other hand, this is a good starting point for exploring a first set of the neighbourhoods, built in the coastal cities and has allowed a critical analysis of the problem at national level.

\section{Conclusions}

The importance of having identified a considerable number of such neighbourhoods in medium-sized cities on the Andalusian coast, does not lies only in its recognition and preservation. Their identification will be a key to the development of other planning policies, based on the recovery of the inherited city, as an alternative to the model of urban sprawl of the second half of the 20th century. It is worth recalling that this planning model has resulted in the destruction of a big part of the natural and agricultural heritage that confirmed the city limits at the beginning of the century.

\footnotetext{
${ }^{14}$ It should be clarified that Mijas is a city with two main urban centres, one indoor (the one that has been protected) and another on the coast (which has suffered the tourism development).
} 
According to the literature review, territorial models that are based on a wide network of medium-sized cities promote more balanced and sustainable systems with relations more fluid and open cities. The authors that have been analysed also come to agree that the scale of these cities facilitates their management, increasing the sense of identity with their neighbourhoods, and therefore, citizen participation processes can be more easily established. These features, among other consequences, will help to reduce the traditional problems of insecurity and conflict, promoting social relations among neighbors (Panerai \& Mangin, 1999). These are features that make them appear as resilient urban structures, with adaptability to the current context in continuous transformation

Consequently, this work recognises the strategic position between the historic city and the new peripheral development as one the characteristics that define the first outskirts. Additionally, this research has shown that the protection of urban centres has led to a more deliberate and controlled urban growth. Besides, diverting private investment in tourism (and consequently the declaration of national interest centres) to other unprotected areas. Indeed, these less anthropized territories should be placed as a focus of debate, due to the ability that they offer to accommodate new tourism developments. The combination of all these factors leads us to presume the necessity of extending the protection beyond the first ring of urban expansion as a preventive measure against the tourist pressure, that is currently being suffered on the Andalusian coast.

Definitely, this research has tried to look into the past to understand the present. Focusing on the errors and some of good practices that were implemented, allows intuit future consequences of the current development patterns and plan territorial strategies related.

\section{Acknowledgments}

The authors are grateful for the financial support from the Research Plan of the University of Seville.

\section{References}

Andrés López, G. (2008). Geografía y ciudades medias en España: ¿a la búsqueda de una definición innecesaria?.[Geography and medium -sized cities in Spain: searching for an unnecessary definition?]. Scripta Nova. Revista electrónica de Geografía y Ciencias Sociales. 12, 270 (August, 2008) 49.URL: http://www.ub. es/geocrit/sn/sn-270/sn-270-49.htm

Arteaga Arredondo, I. (2009).Construir ciudad en territorios urbanizados. Transformaciones en la primera periferia. [Building City at urbanized territories. Transformations in the first periphery].Doctoral Thesis. Universitat Politècnica de Catalunya.URI: http://hdl.handle.net/10803/6971 
Bellet Sanfeliu, C. and Beltrao Sposito, M.E. (1999). Las ciudades medias o intermedias en un mundo globalizado. [The medium or intermediate cities in a globalized world].Ed. Universitat de Lleida.

Bellet Sanfeliu, C. and Llop Torné, J.M. (1999). Ciudades Intermedias y Urbanización Mundial [Intermediate cities and Word Urbanisation]. UNESCO, Ayuntament de Lleida, UIA and Ministerio de Asuntos Exteriores. Lleida.URL: http://www.unesco.org/most/ciudades.pdf

Bernal Santa Olalla, B. (2009). Las casas baratas en Burgos. [Social housing in Burgos].Ed. Dossoles. Burgos.

Blitzer, S. (1988). Outside the large cities; Annotated bibliography and guide to the Literature on Small and Intermediate Centres in the third world. International Institute for Environment and Development (IIED). London.

Bouinot, J. (1991). Les villes moyennes européennes et l'échéance de 1993. [Mediumsized towns and the opening up of the european market in 1993].Annales de Géographie. 100, 561 (1991) 770-796. DOI : https://doi.org/10.3406/geo.1991. 21656

Cabecera Soriano, R. (2014). Los Pueblos de colonización extremeños de Alejandro de la Sota.[Colonization Villages of Alejandro de la Sota in Extremadura].In Colección Investigación. Recuperación de la Memoria Histórica. Consejería de Educación y Cultura de Extremadura.Badajoz.

Calzada Pérez, M. (2006). Pueblos de colonización I, II, III.[Colonization Villages I, II, III]. In Colección Itinerarios de Arquitectura. Fundación Arquitectura Contemporánea.Córdoba.

Campos Sánchez,F. S. (2012). Estrategias urbanas para las ciudades medias andaluzas. [Urban strategies for medium-sizedAndalusian cities]. Doctoral Thesis. Universidad de Granada. URI:http://hdl.handle.net/10481/21763

Campos Sánchez,F. S. and Abarca Álvarez. F.J. (2013). Viejas y nuevas centralidades en las ciudades medias andaluzas: evolución y estrategias urbanas. [Old and new centralities in medium-sized andalusian cities: development and urban strategies].Ciudades, 16 (March, 2013) 145-165.URL: http://www3.uva.es/iuu/ ciud16.htm

Cano García, G. (1990). Jerarquización de los núcleos andaluces.[Hierarchizing of Andalusian Urban Centres] In Geografia de Andalucia (vol. VIII), G. Cano García. Tartessos, Sevilla.

Cano García, G. (1995). Comarcas y articulación del territorio. Cuatro Ejemplos Andaluces.[Regions and articulation of the territory]. Four Andalusians Examples. Revista de Estudios Andaluces. 21 (July, 1995) 47-84. DOI: http://dx. doi.org/10.12795/rea

Cano García, G. (2008).Clasificaciones urbanas en Andalucia: Las ciudades Medias.[Urban classifications in Andalusia: Medium-sized cities].Revista de Estudios Andaluces. 27 (July, 2008) 183-238.DOI: http://dx.doi.org/10.12795/rea

Caravaca Barroso, I.; González Romero, G.; Mendoza Bonet, A. and Silva Pérez, R. (2007). Indicadores de dinamismo, innovación y desarrollo. Su aplicación en ciudades pequeñas y medianas de Andalucía. [Indicators of dynamism, innovation and development. Their application in Andalusian intermediate cities].Boletín de la Asociación de Geógrafos Españoles, 43. (January, 2007) 131254.URL:http://www.age-geografia.es/ojs/index.php/bage/issue/view/58

Centenas Soler, M. (2010).Los pueblos de colonización de Fernández del Amo. [Colonization Villages of Fernández del Amo].In Colección Arquia-Tesis. Fundación Arquia. Barcelona. 
Christaller, W. (1933).Die zentralen Orte in Suddeutschland. English Translation by J. Fischer (1966). Central Places in Southern Germany. Prentice Hall. New Jersey.

Del Espino Hidalgo, B. (2015). Sostenibilidad en centros históricos andaluces : las ciudades medias del centro de Andalucia [Sustainability in Andalusian Historic Centres. Intermediate Cities in the Centre Andalusia].Doctoral Thesis. Universidad de Sevilla.URI:http://hdl.handle.net/11441/31236

Delgado Viñas, C. (1995). Las pequeñas y medianas capitales de provincia en el proceso de modernización del sistema urbano español. [Small and medium-sized provincial capitals in the process of modernization of the Spanish urban system].Universidad de LasPalmas de Gran Canarias.

Díaz Quidiello, J. L. (2007).Las ciudades medias interiores en el Plan de Ordenación del Territorio de Andalucia.[The medium-sizedinterior cities in the Territorial Plan for Andalusia].PH: Boletín del Instituto Andaluz del Patrimonio Histórico, 63 (August, 2007) 44-53.URL: http://www.iaph.es/revistaph/index.php/revistaph/ issue/view/63\#.V6RzamV7tXg

Ministerio de Fomento (2014). Observatorio de Vivienda y Suelo.Boletín Especial Censo 2011. Parque edificado.[Observatory of Housing and Land. Special Report about Census 2011].Dirección General de Arquitectura, Vivienda y Suelo.Centro de Publicaciones. Madrid.URL: http://www.fomento.gob.es/MFO M.CP.Web/handlers/pdfhandler.ashx?idpub=BAW017

Enguita Puebla, A. and Lopez, I. (1995). Alrededor de Madrid. Una red fuerte de ciudades medianas. Buscando un nuevo modelo descentralizador.[Around Madrid. A strong network of medium-sized cities. Looking for a new decentralization model]. Urbanismo: Revista Oficial del Colegio de Arquitectos de Madrid. 26 (1995) 6-25.

Esteban Alonso, A. and López López, A. (1989). El papel de las ciudades medias en España. Presente y futuro. [The role of the medium-sized towns in Spain. Present and future]. Urbanismo: Revista Oficial del Colegio de Arquitectos de Madrid. 6 (1989) 6-16.

Feria Toribio, J. M. (1984). El sistema urbano andaluz: cuestiones metodológicas y problemas de información. [The Andalusian urban system: methodological issues and information problems].Revista de estudios andaluces, 3 (July, 1984) 125144.DOI: http://dx.doi.org/10.12795/rea

Feria Toribio, J. M. (1993). Los sistemas territoriales de asentamientos en Andalucía: dimensiones básicas y organización territorial.[Territorial systems of settlements in Andalusia: basic dimensions and territorial organisation]. Ed. Universidad de Sevilla.

Ferrer i Aixalá, A. (1998). Els poligons de barcelona.[Housing estates in Barcelona].Ed.Universitat Politècnica de Catalunya.

Gaja Díaz, F. (1989). La promoción pública de la vivienda en Valencia (1939-1976). [Public housing in Valencia].Consellería d'obres Publiques, Urbanisme i Transportes.Valencia.

Galiana Martín, L. and Barrado Timón, D. (2006). Los centros de interés turístico nacional y el despegue del turismo de masas en España.[Centres ofnational tourist interest andthe rise of massive tourismin Spain]. Investigaciones Geográficas, 39 (January-April, 2006) 73-93. DOI: http://dx.doi.org/10.14198/IN GEO2006.39.04

Ganau Casas, J. and Vilagrasa Ibarz, J. (2003). Ciudades medias en España:posición en la red urbana y procesos urbanos recientes[Medium sized cities in Spain: position in the urban network and current urban processes]. InHoracio Capel [Coord.]Ciudades, arquitectura y espacio urbano. [Cities, architecture and urban 
space.] Colección Mediterráneo Económico. Caja Rural Intermediterránea. Cajamar. El Ejido (Almería). URL: http://www.publicacionescajamar.es/publica ciones-periodicas/mediterraneo-economico/mediterraneo-economico-3-ciudadesarquitectura-y-espacio-urbano/20/

García Sánchez, A. J. (2012) Los 27 Centros de Interés Turístico Nacional. Los expedientes conservados en (y de) Andalucia. [The 27 centres of National Tourist Interest. The preserved dossiers in (and of) Andalusia]. Andalucía en la Historia, 37 (July-September, 2012), 32-36.URL:https://www.centrodeestudiosandaluces. es/index.php?mod=publicaciones\&cat=23\&id=2666\&idm

García Vázquez, C. (2004).Ciudad hojaldre. Visiones urbanas del siglo XXI. [Puff pastry city. Urban visions of 21 st Century]. Ed. Gustavo Gili (GG).Barcelona.

García Vázquez, C. (2010).Obsolescencia Urbana: El caso de las barriadas residenciales.[Urban Obsolescence: The case of residential neighbourhoods]. Ciudad Viva. 3 (April, 2010) 4-5. URL: http://www.laciudad viva.org/opencms/ opencms/revistas/num003/rev03.html

Gault, M. (1989). Villes intermediaires pour l'Europe?[intermediate cities for Europe?] Syros-Alternatives.Paris.

Glendinning, M. (2008). Postwar Mass Housing. Docomomo Journal, 39 (September 2008).

Gutiérrez Mozo, M.E. and Caro Gallego, C. (2015). La arquitectura de la Obra Sindical del Hogar en la ciudad de Albacete: 1941-1981. [The architecture of the Obra Sindical del Hogar in the town of Albacete: 1941-1981]. Al-Basit. 60 (December, 2015) 123-170. URI:http://hdl.handle.net/10045/53651

Hardoy, J. E. and Satterthwaite, D. (1996). Small and intermediate urban centres: Their role in national and regional development in the third world. Hodder and Stoughton. London.

Hirschman A. O. (1958). The Strategy of Economic Development Yale University Press. New Haven, Conn.

Junta de Andalucía (1983). Propuesta de Comarcalización. Documento para información pública.[Regional division proposal. Document for public information]. Consejería de Política Territorial y Energía.Sevilla.

Junta de Andalucía (1986). Andalucía, Sistema de Ciudades. [Andalusia, System of cities]. Consejería de Obras Públicas y Transporte.Sevilla.

Junta de Andalucía (1990). Bases para la Ordenación del Territorio de Andalucia. [Basis for Territorial Planning of Andalusia].Consejería de Obras Públicas y Transporte.Sevilla.

Junta de Andalucía (2001). Análisis urbanistico de centros históricos de Andalucía: ciudades medias y pequeñas. [Urban analysis of historical centres in Andalusia: medium and small cities]. Dirección General de Ordenación del Territorio y Urbanismo. Consejería de Obras Públicas y Transportes de Andalucía. Sevilla.

Junta de Andalucía (2006). Plan de Ordenación Territorial de Andalucía (POTA). [Territorial Plan for Andalusia]. Dirección General de Planificación. Consejería de Obras Públicas y Transporte. Servicio de Publicaciones. Sevilla.URL: http://goo.gl/XfjmZj

Laborie, J.P. (1993). Les villes moyennes face à la métropolisation. [Médium-sized cities against métropolisation.]. In M. Bonneville (Ed.),L'avenir des villes excellence et-ou diversité. [The future of cities, excellence and-or diversity]. Programme pluriannuel en sciences humaines Rhône-Alpes. Lyon.

Léo, P-Y.; Philippe, J.; Camacho Ballesta, J. A.; Monnoyer, M.; Navarro Espigares, J. L. and Stare, M. (2010). Services et hautes qualifications, un noveau défi pour le développement des villes moyennes. [Services and high qualifications, a new 
challenge for the development of medium-sized cities]. Économies et Sociétés. 44, 2 (2010) 139-172.

Ley de Zonas y Centros de Interés Turístico Nacional[Law ofZones and Centres of National Tourist Interest ] (Law 197/1963). Boletín Oficial del Estado, no 313, 1963, 31st December.URL:https://www.boe.es/diario_boe/txt.php?id=BOE-A$1963-22673$

Ley de defensa, conservación y acrecentamiento del PatrimonioHistórico-Artístico Nacional[Law of defence, conservation and enlarging of the National HistoricArtistic Heritage](Lawof 13th May1933).Gaceta de Madrid. $\mathrm{n}^{\circ}$ 145, 1933, 25th May. URL: https://www.boe.es/datos/pdfs/BOE//1933/145/A01393-01399.pdf

Ley de Patrimonio Histórico Español[Law of Spanish Historical Heritage](Law 16/1985).Boletín Oficial del Estado.n ${ }^{\circ} 155,1985$, 26th June.URL: https://www. boe.es/buscar/act.php?id=BOE-A-1985-12534

Ley de Patrimonio Histórico de Andalucía [Law of Andalusian Historical Heritage] (Law 1/1991).Boletín Oficial de la Junta de Andalucia, $\mathrm{n}^{\circ}$ 59, 1991, 13th July. URL: http://www.juntadeandalucia.es/boja/1991/59/1

Ley de Patrimonio Histórico de Andalucía [Law of Andalusian Historical Heritage](Law 14/2007).Boletín Oficial de la Junta de Andalucía, no248, 2007, 19thDecember.URL:http://www.juntadeandalucia.es/boja/2007/248/1?item=0

Lösch, A. (1940). Die räumliche Ordnung der Wirtschaft.English Translationby W. H. Woglom (1954).The Economics of Location. Yale University Press, New Haven.

Luque Ceballos, I. and Guerrero Quintero, C. (2008).Pueblos de colonización durante el franquismo: la arquitectura en la modernización del territorio rural. [Colonization Villages during Franco's regime: architecture in the modernization of rural area]. Instituto Andaluz del Patrimonio Histórico. Consejería de Cultura de Andalucía. Sevilla.URL: http://www.iaph.es/web/canales/publicaciones/cuade rnos/otras-publicaciones/contenido/cuaderno_0009

Méndez Gutiérrez, R. (2002). Innovación y desarrollo territorial: algunos debates teóricos recientes. [Innovation and regional development: some recent theoretical debates]. EURE: Revista Latinoamericana de Estudios Urbanos Regionales. 28, 84 (September, 2002) 63-83. URL:http://www.redalyc.org/articu lo.oa?id=19608404

Méndez Gutiérrez, R. and Romeiro, P.(2008). Las ciudades del conocimiento: revisión critica y posibilidades de aplicación a las ciudades intermedias.[The knowledge cities: critical revision and applicability to intermediate cities].Scripta Nova. Revista electrónica de Geografía y Ciencias Sociales. 12, 270 (August, 2008), 50. URL: http://www.ub.edu/geocrit/sn/sn-270/sn-270-50.htm

Méndez Gutiérrez, R.; Melero Guillo, A. M. and Calatrava Andrés, A. (2008). Desarrollo territorial policéntrico y ciudades intermedias: recursos productivos $y$ dinámicas económicas locales en Andalucía. [Policentric territorial development and medium size cities: production resources and local economic dynamics in Andalucía ]. Estudios Geográficos. 69, 265 (July-December 2008) 637-663. DOI: https://doi.org/10.3989/estgeogr.0429

Méndez Gutiérrez, R.; Michelini, J.J. and Romeiro, P.(2006). Redes socioinstitucionales e innovación para el desarrollo de las ciudades intermedias. Ciudad y Territorio. Estudios Territoriales. 38, 148 (April- June, 2006) 377-395. Madrid: Ministerio de Vivienda.

Molina Costa, M. and Rubio del Val, J. (2010). Estrategias, retos y oportunidades en la rehabilitación de los polígonos de viviendas construidos en España entre 1940 y 1980.[Strategies, challenges and opportunities in the rehabilitation of collective 
housing neighbourhoods built between 1940 and 1980 in Spain].Ciudades: Revista del Instituto Universitario de Urbanística de la Universidad de Valladolid. 13 (July, 2010)15-17. URL: http://www3.uva.es/iuu/ciud13.htm

Monclús Fraga, F. J. and Díez Medina, C. (2015). El legado del Movimiento Moderno. Conjuntos de vivienda masiva en ciudades europeas del Oeste y del Este. No tan diferentes... [The legacy of the Modern Movement. Massive house sets in Eastern and Western European cities. Not so different...]. Rita: Revista Indexada de Textos Académicos. 3(April, 2015)88-97.URL: http://ojs.redfundamentos.com/ index.php/rita/article/view/59/64

Moya González, L. (2008). Vivienda Social en Europa: Alemania, Francia y Reino Unido desde 1945. [Social housing in Europe: Germany, France and Netherlands since 1945].Mairea Libros.Madrid.

Moya González, L.; Ezquiaga Domínguez, J.M and Inglés Musoles, F. (1983),Barrios de promoción oficial in Madrid, 1939-1976. [Public Neighbourhood in Madrid, 1939-1976]. Colegio Oficial de Arquitectos de Madrid.

Panerai, P. and Mangin, D. (1999). Projet urbain. Colection Eupalinos. Ed. Parenthèses. Paris

Pérez Escolano, V. (2005). Pueblos de colonización 1939-1971 ¿Recuperar del patrimonio rural franquista?[Colonization Village 1939-1971. Recover Franco's rural heritage?PH: Boletín delInstituto Andaluz del Patrimonio Histórico. 52 (February, 2005) 36-125.URL: http://www.iaph.es/revistaph/index.php/revistap $\mathrm{h} /$ issue/view/51\#.V6S95GV7tXg

Pérez Prieto, C. and Marmolejo Duarte, C. (2008). La localización intrametropolitana de las actividades de la innovación: un análisis para la región metropolitana de Barcelona.[The intrametropolitan location of innovative firms: an analysis for Barcelona Metropolitan Region]Scripta Nova. Revista electrónica de Geografía y Ciencias Sociales. 12, 270 (August, 2008) 153. URL: http://www.ub.edu/geocrit/ sn/sn-270/sn-270-153.htm

Perroux, F.(1955).Note sur la notion de poles croissance. [Note on the concept of growth poles]. Economic Appliquee, 8(April, 1955) 307- 320

Pie Ninot, R. (2009).La ciudad de la residencia (Residential city). In C. J. Rosa Jiménez (Ed.), Las Barriadas de la Carretera de Cádiz. Hacia un modelo sostenible de Rehabilitacion Integral Urbana y Arquitectónica.[Carretera de Cádiz district. Towards a sustainable model of urban and architectural integral rehabilitation]. Ed. Universidad de Málaga. URL: http://www.juntadeandalucia. es/fomentoyvivienda/portal-web/web/areas/vivienda/texto/88813618-77e9-11e1b3ef-6583fdb537d9

Plotnicov, L. (1994). El atractivo de las ciudades medias. [The attractiveness of medium-sized cities].Estudios Demográficos y Urbanos. 9, 2 (May-August, 1994) 283-301. URI: http://www.jstor.org/stable/40314743

Pozo Municio, J. M. and López Trueba, I. (2004). Modelos alemanes e italianos para España en los años de la postguerra. [German and Italian Models for Spain in postwar years].Ed.Universidad de Navarra.

Queiro Quijada, R. (2016).Patronato Municipal y Real Patronato de Casas Baratas de Sevilla. Aportaciones a la conformación de la ciudad a través de la vivienda social: 1913-1986. [Municipal and Royal Housing Patronage Foundations in Seville. Contributions to the city formation through social housing: 19131986].Doctoral Thesis. Universidad de Sevilla.URI: http://hdl.handle.net/11441/ 36284 
Reinoso Bellido, R. (2005). Topografia del Paraíso. La construcción de la ciudad de Málaga entre 1897 y 1959 [Topography of Paradise. The construction of the city of Malaga between 1897 and 1959].Colegio Oficial de Arquitectos y Colegio Oficial de Aparejadores y Arquitectos Técnicos de Málaga.

Rodríguez Martínez, F. (2008). Las ciudades medias andaluzas. Cambios básicos durante el último medio siglo.[The medium-sized Andalusian cities. Basic changes over the last half century].In J. Bosque Sendra and M.A. Martín Lou (Coord.).Homenaje a Joaquín Bosque Maurel: Secretario General de la Real Sociedad geográfica (2003-2008). [Tribute to Joaquín Bosque Maurel: General Secretary of the Royal Geographical Society]. Real Sociedad Geográfica. 199238.

Rodríguez Martínez, F. and Sánchez Escolano, L.M. (2010) Sobre la nueva dimensión territorial de las ciudades medias en Andalucía. [About the new territorial dimension of the medium-sized cities in Andalusia]. In C. Cornejo Nieto, J. Morán Sáez and J. Prada Trigo (Coords.) Ciudad, territorio y paisaje: Reflexiones para un debate multidisciplinar.[City, territory and landscape: Reflections for a multidisciplinary discussion]. CSIC, Madrid.

Sambricio, C. (2003). Un siglo de vivienda social (1903-2003). [A century of social housing (1903-2003]. Ed. Nerea. Madrid

Sambricio, C.(2004). Madrid, vivienda y urbanismo. 1900-1960: de la normalización de lo vernáculo al plan regional. [Madrid, housing and urbanism. 1900-1960: from the vernacular normalization to the regional plan]. Ed. Akal. Madrid.

Sambricio, C. (2008). 100 años de historia de la intervención pública en la vivienda y la ciudad. [100 years of public intervention in housing and the city].Ed. AVS. Madrid.

Sánchez Escolano, L. M. (2009). Las redes de ciudades medias en la provincia de Granada: transformaciones recientes y nuevas tipologías (1950- 2008). [Networks of medium-sized cities in the province of Granada: recent changes and new typologies(1950- 2008)]. Cuadernos Geográficos, 46 (July, 2010) 111-138. URL:http://revistaseug.ugr.es/index.php/cuadgeo/article/view/633/720

Sánchez Fuentes, D and Gallardo Ramirez, C. (2015). Silencio Cómplice. In Proceedings Congreso en Ruta Litoral. Destino N-340 (Sevilla, Spain. May 2728, 2015).

Secchi, B. (1989). Un progetto per l'urbanistica.[A project for the urbanism]. Giulio Einaudi. Turín.

Terán Troyano, F. de (1996). Evolución del planeamiento urbanístico (18461996).Ciudad y Territorio: Estudios Territoriales. 28, 107-108, (February, 1996), 167-184. Ministerio de Vivienda. Madrid.

Tostões A. and Ferreira Z. (2016). Housing Reloaded facing Post-War Housing Complexes in Europe.Docomomo Journal, 54 (Abril 2016).

Vilagrasa Ibarz, J. (1999). Las ciudades pequeñas y medias en España.[Small and medium-sized cities in Spain]. In Proceedings. III Coloquio de Geografía Urbana: La ciudad. Tamaño y crecimiento. (Antequera, Spain, June 24 -26, 1996).Asociación de Geógrafos de España (AGE).Universidad de Málaga. 17-49. 
